\title{
The Relationship Between Thinking Style Differences and Career Choices for High-Achieving Students
}

Mihyeon Kim

College of William and Mary, mxkim3@wm.edu

Follow this and additional works at: https://scholarworks.wm.edu/educationpubs

Part of the Gifted Education Commons

\section{Recommended Citation}

Kim, M. (2011). The relationship between thinking style differences and career choices for high-achieving students. Roeper Review, 33(4), 252-262.

This Article is brought to you for free and open access by the School of Education at W\&M ScholarWorks. It has been accepted for inclusion in School of Education Articles by an authorized administrator of W\&M ScholarWorks. For more information, please contact scholarworks@wm.edu. 


\section{Introduction}

Conventional psychometric intelligence tests have been challenged as predictors of students' academic success and real-world performance (Sternberg, Wagner, Williams, \& Horvath, 1995). To explain students' successful school and real-world performance, Sternberg (1994) emphasized individual differences and styles of thinking more than different types of abilities. He believed that intellectual abilities could not be understood without knowing how individuals reacted to environmental situations. In accord with this belief, he developed the mental self-governing theory (1997), which hypothesized that people govern their daily activities with different strategies. He called these different strategies "thinking styles." If students have thinking styles that are different from the favored thinking styles within an educational system, their potential abilities might not be motivated or encouraged. In turn, students might not have the proper opportunities to develop their interests or to pursue their potential career paths. For this reason, there is a need to investigate and understand students' thinking styles, and to provide appropriate educational responses.

The high-school years are a particularly critical time to prepare for the transition to work or college. This study examined individual style differences in thinking among high-achieving students within the two different high-school service-delivery models: the IB program and Governor's School Program. These models are for high-achieving students. Because giftedness does not necessarily produce high performance (Kingore, 2005), this study considers highachieving students as students who have been selected through an IB program or Governor's School Program admission process. The Governor's School Program was developed to meet the needs of high-achieving students by providing an accelerated and enriched curriculum (McHugh, 2006). Likewise, the IB program was designed to address the needs of high-achieving students 
through accelerated curriculum methods (Shaunessy, Suldo, Hardesty, \& Shaffer, 2006). Even though both programs are designed for high-achieving students, a Governors' School Program and an IB program have different academic foci, and different academic foci might demonstrate students' differences in thinking styles, as Gridley's study (2007) showed. Gridley studied thinking styles of artists and engineers, and found that professionals in different areas showed different thinking styles. For example, engineers had higher hierarchic scores than those of artists, and artists preferred to work alone. Therefore, students might have different thinking styles, depending on their schools' different academic foci. Acknowledgement of the relationship between different thinking-style preferences and desired career choices will provide valuable information for serving students based on their individualized needs.

Many parents and teachers think that high-achieving students can do anything, because of their academic achievement in various subjects. However, high-achieving students are often confused about their abilities and preferred domain areas, which are connected to their future career paths (Webb, Gore, Amend, \& DeVries, 2007). As a result, many high-achieving students in college often change their majors, and fail to develop their talents for their future potential career paths (Simpson \& Kaufmann, 1981). As Lubinski and Benbow (2005) suggested, students' preferences are related to satisfaction as well as development of their ability. In addition, Sternberg (1997) raised the issue of that "people whose ways of thinking do not match those valued by the institutions are usually penalized" (p. 8). Thus, the main purpose of considering thinking style is to match ways of thinking to the different types and areas of working in the real world, in order to maximize individuals' abilities and interests. Providing successful career development is another important goal of education. Vocational choice is important in determining quality of life and level of happiness (Amir \& Gati, 2006; Sternberg, 
1997). In addition, high-achieving adolescents, who are likely to make significant future contributions to our society, need proper career education as much as other students do (Gassin, Kelly, \& Feldhusen, 1993). Therefore, more research about thinking styles and career choices for high-school students is needed, to provide suitable guidance for each student. Is there then any relationship between thinking styles and choices of careers? How are thinking styles different, in terms of their desired career choices and their choices of programs with a specific academic focus?

\section{Literature Review}

Because intelligence tests have been challenged as predictors of academic accomplishment in school and of real-world performances of students, many researchers have explored various styles of individuals to explain students' success in school and real-world performance (Sternberg, Wagner, Williams, \& Horvath, 1995). Although researchers are interested in thinking styles, style research has not been limited to the cognitive aspects; in fact, it has explored broad areas of individual differences in thinking (Dunn, Dunn, \& Price, 1978; Furham, 2008; Kagan, 1965; Myers \& Myers, 1993; Rayneri, Gerber, \& Wiley, 2006; Riding \& Rayner, 1998; Thomson \& Mascazine, 2000; Witkin, 1976). Various concepts of styles have been introduced to explain individual differences among people, and any single style theory cannot explain individual differences fully, as the researchers cautioned. Each of the different approaches has explored distinct areas, and knowledge of these distinct areas will help to develop an understanding of styles.

Several researchers have provided a comprehensive review of the cognitive-centered approach, activity-centered style research, the personality-centered approach, and the mental self-government approach (Sternberg, 1997; Riding \& Rayner, 1998). Even though mental self- 
government theory might be included in the cognitive-centered approach, it also embraces personality factors in attempting to suggest a more comprehensive approach to explaining thinking styles. Table 1 shows the range of different approaches represented across the literature.

(Insert table 1 about here)

\section{Cognition-Centered Approach}

A psychometric measure for understanding intelligence was the main issue in the early stages of cognitive research. However, criticisms of IQ measurements of intelligence led many researchers to an interest in cognitive styles, and they developed various style theories (Bartholomew, 2004; Dunn, Dunn, \& Price, 1978; Flynn, 1991; Furham, 2008; Gardner, 1985; Myers \& Myers, 1993; Rayneri, Gerber, \& Wiley, 2006; Riding \& Rayner, 1998; Thomson \& Mascazine, 2000; Vernon, 1973; Witkin, 1976). Because cognitive style is a critical determinant for an individual's behavior and learning, a number of definitions of cognitive styles have been developed. However, a universally accepted, clear definition does not exist. In an attempt to clarify cognitive styles, Riding and Rayner (1998) stated that cognitive style is an individual's consistent approach to "organizing and representing information" (p. 8), and listed 17 different models related to cognitive styles. Grigorenko and Sternberg (1995) organized a list of 14 different cognitive styles. Even though these lists include commonly used definitions, they do not contain complete theories about cognitive styles. Over 30 different approaches have been used to define cognitive styles (Riding \& Rayner, 1998), and this broad range of cognitive styles often extended beyond the preferred pattern of organizing and representing information. Cognitive styles do not have a clear boundary to explain; they cover, rather, the boundaries of the human mind and relate to personality characteristics. Many researchers agree on this issue and 
suggest performing more studies about the relationship between cognitive style and personality (Grigorenko \& Sternberg, 1995; Kirton, 2003).

Personality-Centered Approach

Even though personality and intelligence are two distinct domains, many psychological researchers believe that personality styles are mostly related to cognition, and consider personality a determinant of human behaviors. As cognition-centered research about style has made clear, personality and cognition interact with each other. In the personality research area, two different labels, type and traits, are used to indicate personality. Types are used to refer to categories such as depression, anxiety, and schizophrenia; traits are used to refer to distinct differences, but are normally distributed on a continuum (Furham, 2008). A personality-centered approach to styles is close to the approach to traits, in terms of showing distinct differences among individuals. However, style is different from traits, since styles influence "cognitive function, interest, values, and personality development” (Ross, 1962, p. 76).

\section{Activity-Centered Approach}

Educators have realized that intelligence tests are not enough to understand students' individual differences in classrooms and schools, and have begun to show interest in the activity-centered approach in order to understand students better (Grigorenko \& Sternberg, 1995). Educators believed that these understandings would lead to improved instruction, and result in enhanced student achievement. People identified the activity-centered approach as also being a learningcentered approach. Many researchers understand that learning styles are related to the various study strategies, but the definitions of learning style extended into the following categories (Riding \& Rayner, 1998). 
1. A focus on the learning process - individual differences related to interaction with the environment.

2. Individual differences in pedagogy.

3. The aim of developing new constructs and concepts of learning style.

4. The enhancement of learning achievement.

5. The construction of an assessment instrument as a foundation for the exposition of theory (p. 50).

Even though this theory emphasizes the preferences of learning, the preferences are focused on the elements influencing a person's ability, rather than on categorizing the preference of the learning process itself, aside from abilities, so that the activity-centered approach is differentiated from a thinking-style approach.

Mental Self-Government Theory

Thinking style is one of many types of style studied, and it is not very different from the definition of cognitive style. Some researchers consider cognitive styles to be thinking styles, and others argue thinking style to be an element of cognitive styles (Jones, 2006). However, Sternberg intended to distinguish thinking style from cognitive styles, particularly in relation to abilities. Even though style research excludes abilities, cognitive styles could not make a clear distinction between style and abilities.

Therefore, Grigorenko and Sternberg (1995) defined thinking style as "a preferred way of expressing or using one or more abilities" (p. 220), and proposed a model of mental selfgovernment for identifying thinking styles and how intelligence is primarily directed to understanding preference, rather than abilities. However, the mental self-government theory is not separate from other style research. As Allport (1937) argued, and Sternberg agreed (1997), 
thinking style cannot be separated from the structural consistency of personality. In addition, the preference for reacting to the environment and the adaptive reaction toward new information cannot be very different from thinking style. Therefore, thinking style is the preference for representation and processing of information in the mind, bound to the constituent structure of personality, the consistent way of interacting with the environment, and adapting new information. Then, preferences shape expressive behaviors and styles.

The basic idea of his mental self-government theory is that people need to govern their minds, and these governing activities need to be responsive to environmental changes, just as a government needs to be responsive to changes in our society (Sternberg, 1997). Sternberg proposed 13 thinking styles within five dimensions of mental self-government: functions (legislative, executive, and judicial thinking styles), forms (hierarchical, oligarchic, monarchic, anarchic thinking styles), levels (global and local thinking styles), scopes (including internal and external thinking styles), and leanings (liberal and conservative thinking styles). Table 2 provides a summary of these defined styles.

\section{(Insert table 2 about here)}

Sternberg (1997) stressed individual differences and addressed the point that style research should provide a basis for matching students' styles with educational approaches. This would allow students to identify proper career paths based on their preferences, and to experience appropriate career development toward their identified career paths. Therefore, the purpose of various thinking style research is to promote learning based on individual differences and to achieve better performance in schools, as well as in the work setting, by maximizing individuals' potential abilities (Cano-Garcia \& Hughes, 2000). Then, how are an individual's different potential abilities related to different thinking styles? Park, Park, and Choe (2005) 
attempted to find the relationship between thinking styles and scientific giftedness in Korea, as measured by the Scientific Giftedness Inventory (SGI; Shim \& Kim, 2003). They found that liberal, conservative, and judicial styles are positively related to scientific giftedness. However, cultural differences might influence individual preference differences, according to the study by Park, Park, and Choe.

Accordingly, in the real world beyond the school setting, Schimid (2001) called attention to different thinking styles between theorists and designers in engineering and science. He perceived two different thinking styles: theorists consider tradition, analogy, theoretical beauty, and logical reasoning as sources of knowledge, whereas designers, who are the practitioners, consider gaining experience as a knowledge source for reaching a different method for solving problems. He urged that editors should accept different writing styles, even though practitioners' writing styles are different from traditional scholarly writing styles, in order to promote designers' future contributions to the field. Considering different thinking styles may maximize an individual's abilities and real-world areas of interest in work. Therefore, more research about thinking styles and career choices for high-school students is needed, to provide suitable guidance for each student.

The following research questions focus on seeking answers to two primary inquiries associated with the thinking style differences of high-achieving students.

1. How are thinking styles related to choice of desired career?

2. How are thinking-style preferences of high-achieving students attending a Governor's School Program in science and technology different from those of the high-achieving students participating in International Baccalaureate (IB) programs with a focus on the liberal arts? 


\section{Instrumentation}

Two instruments - the Thinking Style Inventory and A Questionnaire Related to Desired Career Choices - were used in this study to examine thinking style preferences and career choices among high-achieving students. The Thinking Style Inventory (TSI) is a self-reporting instrument that assists in determining a preferred thinking style of an individual. The reliability of the Thinking Style Inventory was investigated by Dai and Feldhusen (1999). In their study, data were obtained from 96 students, ages 12-17, who attended a summer residential program for the gifted. The results of the alpha reliability coefficients ranged from .64 to .89, and had an average alpha reliability coefficient of .75. However, Black and McCoach (2008) examined the psychometric properties of the Thinking Style Inventory, and omitted 64 original items based on their subscale- and item-level confirmatory factor analysis, post hoc item-level exploratory factor analysis, and subscale score reliability analysis. Thirty-two original items were retained, including five subscales of liberal/progressive, external, hierarchic, judicial, and legislative/selfreliant style of thinking, and retained 32 items resulted in internal consistency reliabilities ranging from .729 to .863. This study applied Black and McCoach's suggestions for the Thinking Style Inventory (See Table 3).

\section{(Insert table 3 about here)}

In addition to the Thinking Style Inventory, the researcher constructed a questionnaire to collect demographic information and to examine the desired career choices. The questionnaire was sent to four experts in gifted education to verify that the content represented the information accurately and was clearly, and they provided comments related to clarification of wording and organization of questionnaire to represent content to be tested more clearly. The questionnaire was revised based on their comments. The instrument contains four demographic questions and 
one question asking their desired career choices with check boxes. Choices for their desired career paths include eighteen career paths, which were categorized by CollegeBoard (http://www.collegeboard.com/csearch/majors_careers/profiles/).

\section{Data Collection and Analysis}

Data were gathered through program coordinators in the participating schools. Two groups of high-achieving students that were attending a Governor's School focusing on science and technology or International Baccalaureate (IB) programs with a focus on the liberal arts were asked to participate in this study. A total of 209 responses out of 283 (74\%) were received from students that were selected through an IB program or Governor's School program admission process. For the IB program, students had to be enrolled in Algebra I, Geometry, or Algebra II or a higher level math with a grade of B or better, and in French I, Spanish I, or higher with a grade of B or better, and in Advanced English 8 with a grade of B or better. In addition, the students' GPAs had to be 3.0 or higher for the first semester of the eighth grade year. A personal interview and five recommendation letters were required to be admitted in the IB program. For Academic Year Governor's School programs, students were selected based on PSAT scores, teacher recommendations, and math and science grades through $10^{\text {th }}$ grade. Out of 209 participants, 95 students (45\%) were attending IB programs, and 114 students (55\%) were attending a Governor's School. With regard to gender, 104 students were male and 105 students were female. The students' age range was 15 to 18 years, and the average age was 16.8 years.

First, descriptive statistics for each group were calculated; mean scores and standard deviations were computed for demographic information and the Thinking Style Inventory subscale scores. For Research Question 1 about the relationship between thinking styles and desired career choices, logistic regression was conducted to predict the career choices of high- 
achieving students based on the predictor of thinking styles. Logistic regression is a type of multiple regression analysis, which is used to determine the statistical significance of differences among groups of participants if there is significant prediction of participants' scores on the continuous dependent variable (Field, 2009; Grimm \& Yarnold, 1995). However, logistic regression is used with a categorical dependent variable and a continuous or categorical predictor variable (Field, 2009). Since the dependent variable of career choice in this study was a categorical variable, this study used logistic regression to predict students' desired career choices according to different thinking styles.

In addition to the correlational research design, this study used a causal-comparative research design for Research Question 2. Causal-comparative research is a nonexperimental type of study, and the purpose is to identify the cause and effect relationship between or among different groups (Fraenkel \& Wallen, 1993; Gall, Gall, \& Borg, 2007). Results from this research design should be interpreted in light of its limitations, and this method is usually used for initial exploratory investigation to investigate differences that already exist between or among groups because the researcher does not manipulate independent variables (Gall, Gall, \& Borg, 2007). The causal-comparative design "involves selecting two or more groups that differ on a particular variable of interest and comparing them on another variable or variables" (Fraenkel \& Wallen, 1993, p. 321). This study determined the thinking style differences between students in a Governor's School Program and students in IB programs. Multivariate analysis of variance (MANOVA) was used to determine whether the means from the two groups differed significantly (Gall, Gall, \& Borg, 2007). This test is selected because of a multitude of factors associated with the dependent variable of thinking style. MANOVA testing examined 
differences in all of the five different thinking styles between two groups of students to address Research Question 2.

\section{Research Findings}

\section{Findings Related to Research Question 1}

The first research question associated with this study asked, How are thinking styles related to desired career choice? This question was addressed by using logistic regression analysis because the dependent variable represents categorical data, while the independent variable is continuous. Logistic regression analyses were used to determine which thinking styles would best predict students' desired career choices, and allowed the researcher to assess a model's ability to predict students' desired careers with different thinking styles (Field, 2009; McCoach \& Siegle, 2003). Based on the results of logistic regression analysis, thinking styles were good predictors for whether students choose social science or computers and math areas as their desired career.

Table 4 reports the results in the social science area. The Wald test, which indicates whether an effect of predictors exists, revealed that only liberal/progressive and external thinking styles were statistically significant predictors for whether students choose social sciences as their desired career. People with a liberal/progressive thinking style are inclined to pursue change in their life and work environment, and people with an external thinking style are likely to be sociable and enjoy working with others. The results of the current study showed that those students with a liberal or an external thinking style chose the social science area for their future careers. The odds ratio estimates the change in the odds of membership in the target group. The current study shows that the estimated odds that students with high external thinking style scores would choose a social science as a desired career were 3.10 times greater than students with low 
external thinking style scores. However, the confidence interval for the odds ratio of students with a liberal/progressive thinking style crosses the value of 1 , which means that the odds of these students choosing a social science as a desired career can be either greater or less than students with low liberal/progressive thinking style scores. Because the odds ratio estimation is inconsistent, a liberal/progressive thinking style was not considered as a good predictor even though the $p$ value indicated statistical significance. Therefore, the results demonstrated that high school students who are people-oriented, outgoing, and socially sensitive prefer the social science area for their future careers.

\section{(Insert table 4 about here)}

In the computer and math area, the estimated odds that students with high external thinking style scores would choose this area as a desired career were $73 \%$ less than students with low external thinking style scores (Table 5). The results showed that high-achieving high school students who were people-oriented and outgoing did not prefer computer and math areas for their future careers.

\section{(Insert table 5 about here)}

In the current study, 121 students (59\%) out of 206 students had desired career choices, and Figure 1 shows the details of the career preferences of students in both programs. Students in IB programs preferred medical support, medical treatment, or medical technology, architecture, engineering, drafting, and social science as their future career areas. Students in the Governor's School Program preferred architecture, engineering, drafting, medical support, medical treatment, or medical technology, and science or environment as their future career areas. Even though the desired careers of some students in the IB programs were not consistent with an academic focus 
of liberal arts, students in a program with an academic focus of science and technology showed career preferences consistent with the academic focus of their high school program.

\section{Findings Related to Research Question 2.}

The second research question associated with this study asked, How are thinking style preferences of high-achieving students attending a Governor's School in science and technology different from those of the high-achieving students participating in International Baccalaureate (IB) programs with a focus on the liberal arts? To address Research Question 2, MANOVA was conducted to compare the means of students in two programs for the different thinking styles. As reported in the Table 6, the inter-correlations between the dependent variables were statistically significant $(p<.05)$ and justified the use of MANOVA to reduce Type-I error rates (Weinfurt, 1995).

\section{(Insert table 6 about here)}

Table 7 provides the mean scores and other descriptive information for each of the thinking styles for the entire survey group. Students in the IB programs scored higher in hierarchic, external, and judicial thinking styles; whereas, students in the Governor's Program scored higher in the liberal/progressive and legislative/self-reliant thinking style. To test statistically significant mean differences, a MANOVA test was performed (Table 8). The Wilks's $\Lambda$ of .94 for the effect of the program on the different thinking styles was significant, $\mathrm{F}_{(5 \text {, }}$ 203) $=2.66, p<.05$. The multivariate $\eta^{2}=.06$ indicated that $6 \%$ of the multivariate variance of the dependent variable of thinking styles was associated with the program. Even though different programs explain only $6 \%$ of the variation, the results of univariate ANOVA testing showed statistically significant differences among students in different programs in the mean scores for external and hierarchic thinking styles. Students in IB programs preferred an external thinking 
style, $\mathrm{F}_{(1,207)}=8.51, p<.01$, and a hierarchic thinking style, $\mathrm{F}_{(1,207)}=4.14, p<.05$, over students in the Governor's School Program. High school students attending a program with an academic focus on liberal arts tended to be more people-oriented, outgoing, and valued sharing ideas with others as opposed to students in a program with an academic focus on science and technology. In addition, students attending a program with an academic focus on liberal arts tended to be more systematic and set priorities.

\section{(Insert table 7 about here)}

(Insert table 8 about here)

Discussion, Implications, and Conclusions

\section{Thinking Styles and Career Development}

This study examined the relationship between thinking style and desired career choices of high-achieving students. In predicting students' desired careers with different thinking styles, thinking styles were predictors in terms of the desired career choice of high-achieving students in this study. However, the current study showed results inconsistent with a previous study by Zhang and He (2003). Zhang and He's study demonstrated that students with internal thinking styles and those with external thinking styles both favored studying Internet technology-related work. Students having an external thinking style showed more use of graphic and multi-media work, as well as of both basic- and advanced-level operations, while students with internal thinking style did not show more usage of specific technical operations than did those with other thinking styles. However, students with a strong internal thinking style and students with external thinking styles both showed more favorable attitudes toward the use of computing and information technology in education, as measured by the Computing and Information Technology scale (Zhang \& He, 2003). Their study showed that students with an external 
thinking style reported significantly more knowledge and use of computing and information technology. In contrast, the results of the current study showed that students with external thinking styles do not choose computing or mathematics as desired career areas. One possible explanation for these inconsistent results is that computer- and mathematics-related work requires enduring long working hours and a heavy workload for recognizing, examining, and using even basic principles in solving technical problems. In addition, this field tends to promote working individually, rather than cooperatively, when addressing difficult problems (Career Overview, 2004; Lounsbury, Studham, Steel, Gibson, \& Drost, 2009).

One interesting descriptive finding from this study was that $56 \%$ of students desiring careers in medical support, treatment, or technology $(n=19)$ were enrolled in International Baccalaureate (IB) programs (see Figure 1). This indicates that those students were not enrolled in optimal programs for their desired careers, and that providing more appropriate career counseling may be needed prior to high school. The IB program curriculum focuses on intercultural understanding, and is designed to provide more education in foreign language, speech, and writing (International Baccalaureate Organization, 2009), rather than providing a science-focused curriculum as that of a Governor's School Program. If career guidance is not effective in providing appropriate career-related services or in choosing an appropriate academic program, students might struggle in high school and college to improve their abilities and identify the career area to which they are best suited, as demonstrated by Simpson and Kaufmann's (1981) study. Simpson and Kaufmann's study showed that 55\% of the 322 respondents among presidential scholars undertook the wrong academic major in college, and this might result in a waste of time and expense for individuals, as well as society. 
Compared to students in IB programs, students in the Governor's School Program desired architecture, engineering, drafting, medical support, medical treatment, medical technology, science, or the environment for their future career. Students in a program with an academic focus on science and technology showed career preferences consistent with the academic focus of their high-school program. This indicated that a high-school program with an academic focus on science and technology identified students based on their academic focus better than IB programs did. Some of the differences in programs were signaled by their admissions criteria. The Governor's School Program required that students take advanced math courses to be admitted, but IB programs required only general GPA scores for admission (Virginia Department of Education, 2008; United Nations International Schools, 2008).

In addition, the current study revealed that an external thinking style was a good predictor for a career in the area of social science. Many careers in social science, such as human resources professional, politician, psychologist, and social worker, require interpersonal skills in the workplace; hence, students having an external thinking style might be attracted to a career in social science. The current study did not identify other thinking styles as critical predictors for a future desired career in social science, as Zhang's (2001) study did. Zhang found that Hong Kong secondary students who had judicial or hierarchical thinking styles preferred social sciences and humanities as their careers. One possible explanation for this discrepancy in results between the current study and Zhang's study might be cultural differences. Differences in the job and academic environments between Hong Kong and the United States might have caused different predictions in career areas with different thinking styles. Since previous research suggest that differences in thinking styles exist among different disciplinary areas (Gridley, 2007), more studies should be conducted to understand individual differences in different 
domains. In addition, Zhang's study and this study measured academic achievement in different cultural settings, so perhaps cultural differences might also produce different outcomes related to the relationship between thinking styles and academic performances.

In addition to thinking style differences among high-achieving high-school students with different desired career paths, this study set out to explore thinking style differences among students who are attending different programs with different academic foci. The results of the current study showed that high-school students attending a program with an academic focus on liberal arts tend to be people-oriented, to be outgoing, and to share ideas with others, in comparison to students in a program with an academic focus on science and technology. Therefore, these students need information about a variety of career possibilities utilizing their talent for interaction with people. In addition, students attending a program with an academic focus on liberal arts tended to be systematic and organized when they pursued solutions to problems, in comparison to students in a program with an academic focus on science and technology. This indicates that students in IB programs might need specific guidance and detailed information to help them be prepared for their career development.

\section{Implications for Practice and Future Research}

The current study set out to explore how thinking styles are related to career decisionmaking and different programs among high-achieving students. The data show that thinking styles are a factor in students' career decision-making. In addition, thinking styles are different among students enrolled in different programs. If students' thinking styles are different, counselors, teachers, and parents should recognize these differences as factors in students' optimal career choices. The leaders in designing advanced high-school programs need to set specific requirements to recruit students who fit each of the advanced programs, depending on 
their academic focus. In addition, schools can provide various assessments, including thinking style assessment, to identify students' preferences and talents, to maximize their abilities, and to prepare them for their future careers. Since academic and career advising plays an important role in students' career decisions, counselors need to consider individual styles and backgrounds, such as gender or parental environment, and to bridge students' characteristics, backgrounds, and future career goals.

Several areas are identified for future research in thinking styles and career development for high-achieving students. One is a study of the development of more-accurate instruments that can measure the psychometrics of thinking styles. It appears from previous research that there are not enough accurate and reliable instruments for measuring thinking styles. Many researchers, who studied thinking styles, used The Thinking Style Inventory (1997) as an instrument. However, Black and McCoach (2008) could not find statistical support for the use of full-scale. Even though they provided a revised Thinking Style Inventory with statistical support, which is used in the present study, their results were limited to scores from a single sample of high-school students from four high schools. Therefore, they suggest that researchers and practitioners should be more thoughtful when they have to make important educational decisions, by considering thinking styles. More-accurate instruments representing the psychometrics of thinking styles should be developed in the future for fruitfulness of research results.

Another critical area to be explored is the style difference among experts in different disciplines. Even though this present study was designed to examine different thinking styles of high-achieving adolescents in programs with different academic foci, the students would have had the chance to change their career focus after entering or completing college. However, experts who are actively working in a specific discipline have already experienced a career- 
development process to achieve their current professional status. Therefore, exploring thinking styles of experts in different disciplines might provide a better picture for different thinking-style preferences among students.

In addition, a cross-cultural comparison of thinking styles would identify cultural influences on the development of thinking styles. Previous research in different countries has produced different outcomes concerning style preferences, but the researcher identified no research comparing students from different cultures. Comparison among students from different cultures would provide valuable information about how educators develop career-related education and counseling programs differently in various countries. In addition, exploring how environmental differences cause individuals' different thinking styles would provide valuable information about appropriate educational environments for high-achieving students.

Even though research examining career decision-making processes is not simple to conduct, understanding high-achieving adolescents' career decision-making will have implications not only for individuals, but also for society. Studies related to high-achieving students' career development should therefore be encouraged and disseminated. This study's intent was to explore information about career decision-making in relation to high-achieving students' associated thinking styles. The conclusion from the present study is that career development for high-achieving adolescents should include consideration of thinking styles, in order to provide them with optimum support in making career-related decisions. 


\section{References}

Allport, G. W. (1937). Personality: A psychological interpretation. New York: Henry Holt and Company.

Amir, T., \& Gati, I. (2006). Facets of career decision-making difficulties. British Journal of Guidance \& Counselling, 34(4), 483-505. doi:10.1080/03069880600942608

Bartholomew, D. J. (2004). Measuring intelligence: Facts and fallacies. New York: Cambridge University Press. doi:10.1017/CBO9780511490019

Black, A., \& McCoach, B. (2008). Validity study of the Thinking Styles Inventory. Journal for the Education of the Gifted, 32(2), 180-210.

Brown, D., \& Lent, W. (Eds.). (2005). Career development and counseling: Putting theory and research to work. New York: Wiley.

Cano-Garcia, F., \& Hughes, E. H. (2000). Learning and thinking style: An analysis of their interrelationship and influence on academic achievement. Educational Psychology, 20(4), 413-430. doi:10.1080/713663755

Career Overview (2004). Math careers, jobs and training information. Retrieved May 31, 2009, from http://www.careeroverview.com/math-careers.html

CollegeBoard. (2009). Major \& career profiles. Retrieved January 19, 2009, from http://www.collegeboard.com/csearch/majors_careers/profiles/

Dai, D. Y., \& Feldhusen, J. F. (1999). A validation study of the thinking styles inventory: Implications for gifted education. Roeper Review, 21(4), 302-307. doi:10.1080/02783199909553981

Dunn, R., Dunn, K., \& Price, G. E. (1978). Teaching students through their individual learning styles: A practical approach. Reston, VA: Reston Publishing.

Egeland, B., \& Weinberg, R. A. (1976). The Matching Familiar Figures Test: A look at its psychometric credibility. Child Development, 47(2), 483-491. doi:10.2307/1128805

Field, A. (2009). Discovering statistics using SPSS (3 ed.). Los Angeles: SAGE.

Flynn, J. R. (1991). Asian Americans: Achievement beyond IQ. Hillsdale, New Jersey: Lawrence Erlbaum Associates.

Fraenkel, J. R., \& Wallen, N. (1993). How to design and evaluate research in education. New York: McGraw-Hill Inc. 
Thinking Style Differences and Career Choices 22

Furnham, A. (2008). Personality and intelligence at work. New York: Routledge. doi: $10.4324 / 9780203938911$

Gall, M. D., Gall, J. P., \& Borg, W. R. (2007). Educational research. Boston: Pearson Education, Inc.

Gardner, H. (1985). Frames of mind. Cambridge, MA: BasicBooks.

Gassin, E. A., Kelly, K. R., \& Feldhusen, J. F. (1993). Sex differences in career development of gifted youth. The School Counselor, 41, 90-95.

Gridley, M. C. (2007). Differences in thinking styles of artists and engineers. Career Development Quarterly, 56(2), 177-182.

Grigorenko, E. L., \& Sternberg, R. J. (1995). Thinking Styles. In D. H. Saklofske \& M. Zeidner (Eds.), International Handbook of Personality and Intelligence. New York: Plenum Press.

Grigorenko, E. L., \& Sternberg, R. J. (1997). Styles of thinking, abilities, and academic performance. Exceptional Children, 63(3), 295-312.

Grimm, L. G., \& Yarnold, P. R. (1995). Reading and understanding multivariate statistics. Washington D.C.: American Psychological Association.

Holland, J. L. (1974). Vocational guidance for everyone. Educational Researcher, 3(1), 9-15.

Holland, J. L. (1996). Exploring careers with a typology: What we have learned and some new directions. American Psychologist, 51(4), 397-406. doi:10.1037/0003-066X.51.4.397

International Baccalaureate Organization. (2009). The IB diploma programme. Retrieved January 2, 2009, from http://www.ibo.org/diploma/

Jones, M. S. (2006). Thinking style differences of female college and university presidents: A national study. Marshall University, Huntington, West Virginia.

Kagan, J. (1958). The concept of identification. Psychological Review, 65, 296-305. doi:10.1037/h0041313 PMid:13591457

Kagan, J. (1965). Conceptual development in children. New York: International University Press.

Kingore, B. (2005). High achiever, gifted learner, creative thinker. Plano association for the Gifted and Talented Resource. Retrieved February 15, 2010, from http://www.pptasage.com/PDF\%20files/PAGT_Spring05News.pdf

Kirton, M. J. (2003). Adaption-innovation: In the context of diversity and change. New York: Routledge. 
Lent, R. W., Brown, S. D., \& Hackett, G. (2000). Contextual supports and barriers to career choice: A social cognitive analysis. Journal of Counseling Psychology, 47(1), 36-49. doi:10.1037/0022-0167.47.1.36

Lounsbury, J. W., Studham, R. S., Steel, R. P., Gibson, L. W., \& Drost, A. W. (2009).

Personality traits and career satisfaction of information technology professionals. In Y. K. Dwivedi, B. Lal, M. D. Williams, S. L. Schneberger \& M. Wade (Eds.), Handbook of Research on Contemporary Theoretical Models in Information Systems. Hershey, PA: IGI Global. doi:10.4018/978-1-60566-659-4.ch030

Lubinski, D., \& Benbow, C. P. (2006). Study of mathematically precocious youth after 35 years. Perspectives on Psychological Science, 1(4), 316-345.

McCoach, D. B. \& D. Siegle. (2003). Factors that differentiate underachieving gifted students from high-achieving gifted students. Gifted Child Quarterly, 47(2), 144-154. doi:10.1177/001698620304700205

McHugh, M. W. (2006). Governor's schools: Fostering the social and emotional well-being of gifted and talented students. The Journal of Secondary Gifted Education, 17(3), 50-58.

Messick, S. (1976). Individuality in learning. San Francisco: Jossey-Bass Publishers.

Myers, I. B., \& Myers, P. B. (1993). Gifts differing: Understanding personality type. Palo Alto, CA: CPP Books.

Park, S., Park, K., \& Choe, H. (2005). The relationship between thinking styles and scientific giftedness in Korea. Journal of Secondary Gifted Education, 16(2-3), 87-97.

Rayneri, L. J., Gerber, B. L., \& Wiley, L. P. (2006). The relationship between classroom environment and the learning style preferences of gifted middle school students and the impact on levels of performance. Gifted Child Quarterly, 50(2), 104-118. doi:10.1177/001698620605000203

Riding, R., \& Rayner, S. (1998). Cognitive styles and learning strategies: Understanding style differences in learning and behaviour. London: David Fulton Publishers.

Ross, J. L. (1962). Factor analysis and levels of measurement in psychology. In S. Messick \& J. Ross (Eds.), Measurement in personality and cognition (pp. 69-81). New York: Wiley. Saracho, O. N. (1997). Teachers' and students' cognitive styles in early childhood education. Westport, CT Greenwood Publishing Group. 
Schmid, H. (2001). Theory and practice: Thinking styles in engineering and science. American Journal of Information Systems, 9(1), 106-115.

Shaunessy, E., Suldo, S. M., Hardesty, R. B., \& Shaffer, E. J. (2006). School functioning and psychological well-being of International Baccalaureate and general education students: A preliminary examination. The Journal of Secondary Gifted Education, 17(2), 76-89.

Shim, J. Y., \& Kim, O. J. (2003). A study of the characteristics of the gifted in science based on implicit theory. The Korean Journal of Educational Psychology, 17, 241-255.

Simpson, R. G., \& Kaufmann, F. A. (1981). Career education for the gifted. Journal of Career Education, 7(4), 38-45. doi:10.1177/089484538100800104

Sternberg, R. J. (1994). Allowing for thinking styles. Educational Leadership, 36-40.

Sternberg, R. J. (1997). Thinking styles. New York: Cambridge University Press. doi:10.1017/CBO9780511584152

Sternberg, R. J., Wagner, R. K., Williams, W. M., \& Horvath, J. A. (1995). Testing common sense. American Psychologist, 50(11), 912-927. doi:10.1037/0003-066X.50.11.912

Super, D. E. (1957). The psychology of careers. New York: Harper \& Row.

Super, D. E. (1980). A life span, life space approach to career development. Journal of Vocational Behavior, 13, 282-298. doi:10.1016/0001-8791(80)90056-1

Thomson, B. S., \& Mascazine, J. R. (2000). Attending to learning styles in mathmematics and science classrooms. Retrieved October 28, 2008, from http://www.ericdigests.org/20001/attending.html

United Nations International Schools (2008). International Baccalaureate Program. Retrieved November 6, 2008, from http://www.unis.org/academic_programs/high_school/international_baccalaureate_progra $\underline{\mathrm{m} / \text { index.aspx }}$

Vernon, P. E. (Ed.). (1973). Multivariate approaches to the study of cognitive styles. New York: Academic Press.

Virginia Department of Education. (2008). Virginia governor's school program. Retrieved November 7, 2008, from http://www.doe.virginia.gov/VDOE/Instruction/Govschools/

Webb, J. T., Gore, J. L., Amend, E. R., \& DeVries, A. R. (2007). A parent's guide to gifted children. Scottsdale, Arizona: Great Potential Press, Inc. 
Weinfurt, K. P. (1995). Multivariate analysis of variance. In L. G. Grimm \& P. R. Yarnold (Eds.), Reading and Understanding Multivariate Statistics. Washington D.C.: American Psychological Association.

Witkin, H. A. (1976). Cognitive style in academic performance and in teacher-student relations. In S. Messick (Ed.), Individuality in Learning. San Francisco: Jossey-Bass, Inc.

Zhang, L. (2001). Do styles of thinking matter among Hong Kong secondary school students? Personality and Individual Differences 31(3), 289-301. doi:10.1016/S0191$\underline{8869(00) 00136-7}$

Zhang, L.-f., \& He, Y. (2003). Do thinking styles matter in the use of and attitudes toward computing and information technology among Hong Kong university students? Journal of Educational Computing Research, 29(4), 471-493. doi:10.2190/3M8D-1D56-V60C$\underline{\text { BHR5 }}$ 
Table 1

Summary of Different Approaches to Styles

\begin{tabular}{lll}
\hline Approaches to styles & Definition & Researchers \\
\hline $\begin{array}{l}\text { Cognitive-centered } \\
\text { approach }\end{array}$ & $\begin{array}{l}\text { Styles are an individual's consistent approach to } \\
\text { organizing and representing information (Riding \& } \\
\text { Rayner, 1998) }\end{array}$ & $\begin{array}{l}\text { Kagan (1965) } \\
\text { Kirton (1976) } \\
\text { Witkin (1976) }\end{array}$ \\
$\begin{array}{l}\text { Personality-centered } \\
\text { approach }\end{array}$ & $\begin{array}{l}\text { Styles are determined by an individual's personality } \\
\text { (Myers \& Myers, 1993) }\end{array}$ & Myers \& Myers (1993) \\
Activity-centered approach & $\begin{array}{l}\text { Styles are related to the various styles of study strategies } \\
\text { (Riding \& Rayner, 1998) }\end{array}$ & $\begin{array}{l}\text { Dunn, Dunn, \& Price } \\
\text { (1978) }\end{array}$ \\
$\begin{array}{l}\text { Mental self-government } \\
\text { theory approach }\end{array}$ & $\begin{array}{l}\text { Styles are determined by activities of people's mind } \\
\text { analogous to governmental activities (Sternberg, 1997) }\end{array}$ & Sternberg (1997) \\
\hline
\end{tabular}

Table 2

Summary of Styles of Mental Self-Government Theory

\begin{tabular}{ll}
\hline Style & Characterization \\
\hline FUNCTIONS & \\
$\begin{array}{l}\text { Legislative } \\
\text { Executive } \\
\text { Judicial }\end{array}$ & $\begin{array}{l}\text { Like to create and do new things, and have little assigned formation } \\
\text { Like to follow disciplines, and prefer to be in the existing structure } \\
\text { Like to judge and evaluate people and things }\end{array}$ \\
$\begin{array}{l}\text { FORMS } \\
\text { Monarchic } \\
\text { Hierarchic } \\
\text { Oligarchic } \\
\text { Anarchic }\end{array}$ & $\begin{array}{l}\text { Like to do one thing at a time with devotion regardless of the situation } \\
\text { Like to do many things at once through setting priorities for work } \\
\text { Like to do many things at once without setting priorities }\end{array}$ \\
LEVELS & $\begin{array}{l}\text { Like to take a random approach to problems; dislike systems, } \\
\text { guidelines, and practically all constraints }\end{array}$ \\
Local & \\
& Like to deal with a big abstract picture rather than focusing on details \\
LCOPE & abstract big goals \\
Internal & \\
External & Like to work alone and tend to be introverted \\
LEANING & Like to work with others, and be sociable
\end{tabular}


Liberal Like to do things in new ways and deny tradition

Conservative Like to do things in traditional way

Table 3

Thinking Style Inventory Subscales

\begin{tabular}{|c|c|c|c|}
\hline Thinking styles & Characteristics & $\begin{array}{l}\text { Number of } \\
\text { Items }\end{array}$ & $\begin{array}{l}\text { Coefficient } \\
\text { alpha }\end{array}$ \\
\hline Liberal/Progressive style & $\begin{array}{l}\text { Likes to try new methods and find new strategies } \\
\text { to solve problems }\end{array}$ & 9 & .86 \\
\hline External style & Likes to work and share ideas with others & 6 & .83 \\
\hline Hierarchic style & $\begin{array}{l}\text { Likes to order ideas and things to do by perceived } \\
\text { importance }\end{array}$ & 6 & .77 \\
\hline Judicial style & Likes to compare and rate ideas or views & 5 & .73 \\
\hline Legislative/Self-reliant style & $\begin{array}{l}\text { Likes to work based on their ideas and strategies } \\
\text { when doing a task }\end{array}$ & 6 & .78 \\
\hline
\end{tabular}

Table 4

Results of the Logistic Regression Analyses with All Five Predictor Variables in Social Science

\begin{tabular}{|c|c|c|c|c|c|c|c|}
\hline \multirow[t]{2}{*}{ Predictor Variable } & \multirow[t]{2}{*}{ B } & \multirow[t]{2}{*}{$\mathrm{seB}$} & \multirow[t]{2}{*}{ Wald } & \multirow[t]{2}{*}{$\mathrm{df}$} & \multirow[t]{2}{*}{ Odds Ratio } & \multicolumn{2}{|c|}{$\begin{array}{c}95.0 \% \text { CI } \\
\operatorname{EXP(B)}\end{array}$} \\
\hline & & & & & & LL & UL \\
\hline $\begin{array}{l}\text { Liberal/ } \\
\text { Progressive }\end{array}$ & -1.39 & .72 & 3.71 & 1 & $.25^{*}$ & .06 & 1.03 \\
\hline External & 1.13 & .50 & 5.06 & 1 & $3.10 *$ & 1.16 & 8.26 \\
\hline Hierarchic & -.33 & .38 & .76 & 1 & .72 & .34 & 1.52 \\
\hline Judicial & .48 & .44 & 1.16 & 1 & 1.61 & .68 & 3.85 \\
\hline $\begin{array}{l}\text { Legislative/ } \\
\text { Self-reliant }\end{array}$ & -.59 & .89 & .44 & 1 & .55 & .10 & 3.19 \\
\hline
\end{tabular}

Note. $\mathrm{CI}=$ confidence interval; $\mathrm{LL}=$ lower limit; $\mathrm{UL}=$ upper limit.

$* \mathrm{p}<.05$ 
Table 5

Results of the Logistic Regression Analyses with All Five Predictor Variables in math and technology

\begin{tabular}{|c|c|c|c|c|c|c|c|}
\hline & \multirow[t]{2}{*}{ B } & \multirow[t]{2}{*}{$\mathrm{seB}$} & \multirow[t]{2}{*}{ Wald } & \multirow[t]{2}{*}{$\mathrm{df}$} & \multirow[t]{2}{*}{ Odds Ratio } & \multicolumn{2}{|c|}{$\begin{array}{c}95.0 \% \text { CI } \\
\text { EXP(B) }\end{array}$} \\
\hline & & & & & & LL & UL \\
\hline $\begin{array}{l}\text { Liberal/ } \\
\text { Progressive }\end{array}$ & 3.71 & .79 & 3.62 & 1 & 4.49 & .96 & 20.78 \\
\hline External & 5.06 & .41 & 9.82 & 1 & $.27 * *$ & .12 & .62 \\
\hline Hierarchic & .76 & .44 & .59 & 1 & 1.40 & .59 & 3.34 \\
\hline Judicial & 1.16 & .45 & 1.19 & 1 & .62 & .26 & 1.47 \\
\hline $\begin{array}{l}\text { Legislative/ } \\
\text { Self-reliant }\end{array}$ & .44 & .84 & .25 & 1 & .66 & .13 & 3.39 \\
\hline
\end{tabular}

Note. $\mathrm{CI}=$ confidence interval; $\mathrm{LL}=$ lower limit; $\mathrm{UL}=$ upper limit.

$* * \mathrm{p}<.01$

Table 6

Variable Correlations

\begin{tabular}{lrrrrr}
\hline & $\begin{array}{c}\text { Liberal/ } \\
\text { Progressive }\end{array}$ & External & Hierarchic & Judicial & $\begin{array}{c}\text { Legislative/ } \\
\text { Self-Reliant }\end{array}$ \\
\hline Liberal/Progressive & 1 & $.42^{* *}$ & $.17 *$ & $.40^{* *}$ & $.79 * *$ \\
External & & 1 & $.31^{* *}$ & $.28^{* *}$ & $.30^{* *}$ \\
Hierarchic & & & 1 & $.39 * *$ & $.15^{*}$ \\
Judicial & & & & 1 & $.30^{* *}$ \\
Legislative/Self-Reliant & & & & & 1 \\
\hline
\end{tabular}

$* \mathrm{p}<.05 . * * \mathrm{p}<.01$

Table 7.

Mean Scores and Standard Deviation for Thinking Styles by Program

\begin{tabular}{lcccr}
\hline & \multicolumn{2}{c}{$\begin{array}{c}\text { IB Program } \\
(n=95)\end{array}$} & \multicolumn{2}{c}{$\begin{array}{c}\text { Governor's Program } \\
(n=114)\end{array}$} \\
\cline { 2 - 5 } \multicolumn{1}{c}{ Factors } & $\mathrm{M}$ & SD & $\mathrm{M}$ & SD \\
\hline & & & & 1.08 \\
Liberal/Progressive & 5.01 & .99 & 5.04 & 1.24 \\
External & 5.40 & .99 & 4.94 &
\end{tabular}


Thinking Style Differences and Career Choices 29

\begin{tabular}{lrrrr} 
Hierarchic & 5.08 & 1.06 & 4.77 & 1.14 \\
Judicial & 4.42 & 1.09 & 4.41 & 1.09 \\
Legislative/Self-Reliant & 5.28 & .74 & 5.31 & .92 \\
\hline
\end{tabular}

Table 8

Multivariate and Univariate Analyses of Variance for Different Thinking Styles

\begin{tabular}{|c|c|c|c|c|c|c|c|}
\hline \multirow[b]{2}{*}{ Source } & \multicolumn{2}{|c|}{ Multivariate } & \multicolumn{5}{|c|}{ Univariate } \\
\hline & df & & $\begin{array}{c}\text { Liberal/ } \\
\text { Progressive }\end{array}$ & External & Hierarchical & Judicial & $\begin{array}{c}\text { Legislativ } \\
\text { e/ } \\
\text { Self- } \\
\text { Reliant } \\
\end{array}$ \\
\hline Program & 1 & $2.66^{*}$ & .03 & $8.51 * *$ & $4.14 *$ & .00 & .10 \\
\hline Interaction & 1 & $2382.97 * *$ & $4817.98 * *$ & $4321.48 * *$ & $4112.16^{* *}$ & $3406.68 * *$ & $8237.67 * *$ \\
\hline MSE & & & 1.09 & 1.28 & 1.22 & 1.18 & .71 \\
\hline
\end{tabular}

Note. Multivariate F ratios were generated from Wilks' Lambda statistic.

Multivariate $\mathrm{df}=5,203$. Univariate $\mathrm{df}=1,207$.

$* \mathrm{p}<.05 . * * \mathrm{p}<.01$. 
Figure 1. Selected Career Focus by Program.

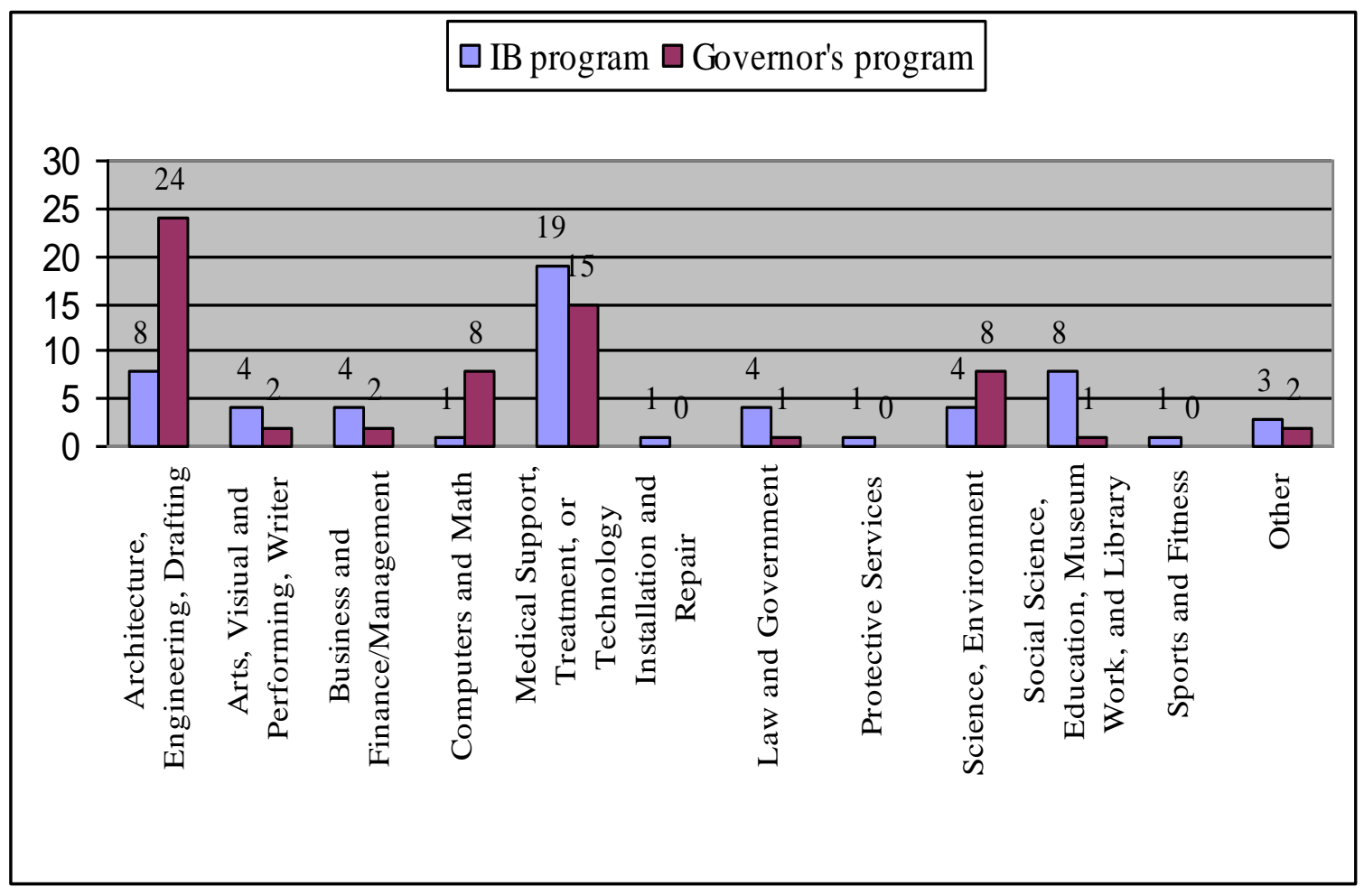

